CEZARY MAŃKOWSKI, Ph.D. ${ }^{1}$

E-mail: ekocm@ug.edu.pl

DARIUSZ WEILAND, M.Sc. ${ }^{1}$

E-mail: d.weiland@ug.edu.pl

BORNA ABRAMOVIĆ, Ph.D. ${ }^{2}$

(Corresponding author)

E-mail: borna.abramovic@fpz.hr

${ }^{1}$ University of Gdańsk, Faculty of Economics

A. Krajowej 119/121, 81-824 Sopot, Poland

2 University of Zagreb,

Faculty of Transport and Traffic Sciences

Vukelićeva 4, 10000 Zagreb, Croatia
Transportation Economy

Preliminary Communication

Submitted: 10 Apr. 2019

Accepted: 2 Oct. 2019

\title{
IMPACT OF RAILWAY INVESTMENT ON REGIONAL DEVELOPMENT - CASE STUDY OF POMERANIAN METROPOLITAN RAILWAY
}

\begin{abstract}
From the regional development point of view new investments are always of great importance as they are mainly expected to boost the regional economy and thus improve the living standard of inhabitants. Also for the literature purposes a new case study on the impact of investments on regional development can be perceived as an added value to the state of the art and thus worthy to be explored. In this research the impact is measured in the following aspects: social, economic, innovation, and environmental, which stand also for the main assessment criteria. Just recently, an opportunity has appeared to explore this subject on the Pomeranian Metropolitan Railway (PMR), which started its operations on $1^{\text {st }}$ September 2015, after five years of construction works and more than a 100-year long history. Thus, the paper presents the impact results of PMR on the development of the Pomeranian region, in the form of qualitative as well as quantitative assessments in the four aspects and on different levels of detail. The final conclusion states that the impact of PMR on the regional development has appeared to be negative in 33\% and positive in $67 \%$.
\end{abstract}

\section{KEY WORDS}

railway; region; investment; assessment;

\section{INTRODUCTION}

The Pomeranian region is located in the northern part of Poland, inhabited by 2.3 million people living on $18,310 \mathrm{~km}^{2}$ of area, relatively well developed, with its main city, Gdańsk, famous for its Solidarity movement. Similar to other regions, its further development depends on many factors, both of internal as well as external origin. The analysed case of the PMR investment is an example of an internal factor whose influence on the Pomeranian region is the object of research. Till now, there have been only popular publications, which promoted the new railway investment in the region, and sometimes initiated a discussion on the role of PMR in the region; however, no scientific analyses on the impact of this investment were done. Therefore, the purpose of this paper is to assess the PMR impact on the Pomeranian region and to present the analysis results. In this research the impact is measured in four aspects: social, economic, innovation, and environmental. These aspects are also used as the main criteria, whose more detailed sub-criteria in the form of text (qualitative) or numeric (quantitative) variables are included in Section 5. Since the main research method is a case study, which is focused on the identification and assessment of impact relations, a general hypothesis in a falsifiable form is formulated as: PMR investment has got a negative impact on the Pomeranian regional development. To verify this thesis a modified falsification method is used, which is adjusted by the authors to the selected case. A broader explanation of the research methods is included in Section 3. The obtained results are presented in the next sections, which are supported by conclusion, which also includes limitations and further research propositions.

\section{LITERATURE REVIEW}

The problem of impact assessment of transportation or logistics investments is not a new one. There is a lot of literature, reports and projects, including feasibility studies, which are focused on that problem [1-3]. Significantly less, but still notable attention in literature is devoted to measuring the investment influence on the regional development. In this context, it is worth mentioning the work of Blum [4], who presented the theoretical and empirical results of the investigation on the effects of transportation investment on the regional growth. Another example is a more detailed 
study by Domańska [5], who analysed the influence of road transport infrastructure on the regional development. These contributions in literature are supported by some institutional publications, above all the OECD report [6], as well as the guidance for governments and transport administrations on how to find empirical evidences on wider impacts of transport infrastructure investment on regional development. Other examples are institutional reports and projects on: the role of transport infrastructure in regional economic development [7]; transport investments and policies on spatial economics [8]; planning, monitoring and evaluation of regional logistics strategy [9], etc. Additionally, a lot of case studies on the abovementioned problem can also be listed; for instance in relation to the development of regions in China [10], Lithuania [11] Slovakia [12], etc. Berchmann [36] in his book pointed out that in formal transportation project evaluation procedure very often vital information, such as accurate costs and demand projections, is largely missing. The author constructed a comprehensive and methodical economic, planning and decision-making framework for the evaluation of proposed transportation infrastructure investment projects. The assessment of investment in traffic-technological projects means a set of activities, whose basic aim is to determine the justification and feasibility of the projects. The decision-making process, including the decision making on investments is an extremely complex one, and the decision-maker has to have a vision of the future and decide/choose accordingly in a modern and flexible manner. Therefore, the decisions need to be the result of a planning and research process based on different methods [37]. The transportation infrastructure projects often involve considerable land use, long-term investments, and huge resources. The results from the literature show that sustainability factors and performance can be categorized under environment, economic, social, engineering/resource utilization and project management [38]. For investigating different transportation infrastructure projects, it is always good practice to use relatively simple and transparent evaluation methods. The evaluation methods usually contain the following important issues: sustainable development, evaluation criteria, and environmental criteria [39]. However, the question of how to measure the impact of transportation investments on the level of regional development, what methods and tools to take, has been raised by all the authors of the mentioned publications.

\section{RESEARCH METHODOLOGY}

Because the research hypothesis: PMR investment has got a negative impact on the Pomeranian regional development, is stated in the falsifiable form, the general verification method is Popper's falsification [13]. According to this method, a lot of evidences, which are found and presented to confirm the hypothesis, do not prove there is not one evidence against it. So, instead of looking for many evidences, which confirm the thesis, it is more logical to find the only one proof to falsify the hypothesis in favour of the alternative one [14]. However, finding a proof against the falsifiable hypothesis does not mean that the alternative (positive) one is true, especially if the social sciences' methods are used and the research object is a complex business case. Thus, the authors propose a modified falsification method in the form of constructing two hypotheses: a negative, and a positive one.

The first one states that the PMR impact on the regional development is negative, while the second one speaks about the positive impact; additionally these two hypotheses do not exclude each other, but exist simultaneously. Of course, a method of measuring the importance, truth or falsehood, probability, weight, etc. of these hypotheses is required. Taking into account the complexity of the analysed case, the authors' scope of research competency and the limitations of the paper format, the so-called point-percentage method of weighting each of these two hypotheses are proposed as follows. Based on the subjective authors' expert assessment of the PMR impact on the regional development in the selected aspects, 100 points are divided between negative and positive hypotheses, respectively, for each selected aspect of assessment, then the points are summed for all the aspects for positive and negative hypotheses separately, and their share in percentage is calculated. Next, this percentage is to be used to state in what percentage the PMR impact on the region has appeared to be negative and positive, respectively.

The above-described point-percentage method requires other methods to evaluate the PMR impact on the regional development. Usually, the cost-benefit analysis is proposed as the main method to assess an investment impact. It includes a set of particular methods of calculating the effectiveness of investments in terms of input and output, as for instance methods of measuring: regional income, costs, net present value, market growth and share, break-even point, payback period, internal return rate, return on investment, etc. $[1,15]$. Consequently, it also means that a lot of variants of the cost-benefit analysis are projected and applied, as for instance: UNIDO method [16], value-added method [1], or cost-effectiveness analysis [15]. Based on the criticism of cost-benefit methods, especially the strong focus on financial criteria and weak focus on other evaluation factors, a multi-criteria analysis (MCA) is proposed in literature [1]. This method combines the cost-benefit analysis with others, not so much financially-oriented methods, like methods of measuring: fitting social needs, standards of living, wealth, poverty, unemployment, social exclusion, innovations, sustainability, etc. Examples of such studies, which, with 
the exception of economic assessment, also evaluate the social and environmental results, as for instance the impact on unemployment, liquidation of social barriers and usage of nature resources can be found in publications on the effectiveness of Trans-European Transport Network commissioned by the European Commission $[8,18]$. Apart from the abovementioned and relatively well-recognised cost-benefit and MCA methods, there is a number of less commonly used qualitative and quantitative methods such as multiplier or econometric ones [5].

In addition, the above considerations made in the research approach also produce the answer to the question how to understand the category of impact? In this paper the impact is understood in terms of input, output, or more broadly - in terms of results and influence, expressed in quantitative units (physical, currency, points, percentage), or expressed in the form of qualitative description of the impact, respectively.

Because the analysed case is a multi-aspect object, some research perspectives have to be taken. Since PMR is a business enterprise as well as a social challenge, the impact of this investment on the Pomeranian region in these two aspects has to be taken without any doubt. Due to the general requirements for any investments to be innovative and sustainable, all four research perspectives have been distinguished for a detailed analysis.

Summarising, in this paper the modified falsification method supported by the so-called point-percentage method is proposed to verify the hypothesis. However, it is understood as a general research approach, which combines other methods, especially the cost-benefit and multi-criteria analyses, applied to the case of PMR. Nevertheless, there can be a confusion, why not use a well-established method of measuring an investment impact, as for instance the previously mentioned cost-benefit method? Apart from the above-presented criticism on the method it should be added that, especially in the case of PMR investment, which is a relatively new one, because it has been operating for less than four years, but a highly complex one, it is more objective to use a set of methods to measure the impact rather than just one of them. As a result, the proposed methodology approach not only allows measuring of the impact on the four perspectives (used also as the main criteria of assessment), but also on different levels of aggregation or details. If a general answer on the impact of the railway line is required, the point-percentage method provides the assessment of positive and negative hypotheses in percentages. If more detailed data on financial or environmental impact are needed, for instance, then the cost-benefit criteria can be found in the qualitative (numbers) or quantitative (text) form in the related sections of the paper. It also means that the used methods do not exclude each other, but, on the contrary, they support each other to produce the most reliable data. Because this methodology approach receives also a theoretical support, more explanation of the used methods is also included in the next Section.

\section{THEORETICAL BACKGROUND}

The above-presented results of literature study and methodology approach are extended by the following theoretical background. As it was mentioned in the Section of literature review, this research falls into the problem of transportation or logistics investment assessment, for which the theories of economic growth or development formulate the broadest theoretical background. Literature review results [31] prove that every economic growth or development model, starting from classical, through neo-classical, up to modern models, treats an investment, explicitly or implicitly, as a factor (mainly in the form of land, labour, and capital), which has a significant impact on the economic growth, verbally expressed in the thesis: the more the investment is used, the greater is the economic development. A representative example is presented by the Keynesian macroeconomic model [32]:

$T E=C+I$

where:

$T E$ - total expenditures,

$C$ - expenditures on consumption, and

$I$ - expenditures on investment.

Since the investment (as well as the consumption) has a multiplied effect on total expenditures, the above model is supported by the so-called multiplier formula [32]:

$$
\triangle T E=\frac{1}{M P S} \cdot \Delta I
$$

where

$\triangle T E \quad$ - change in total expenditure,

$\left(\frac{1}{M P S}\right)$ - marginal propensity to investment, and

$\Delta I \quad$ - change in investment expenditures.

The above outlined macroeconomic theory background for investment is also applicable at a smaller, microeconomic scale, for instance in the regional, industry sector, or supply chain perspective, or even on the level of a single organisation. An example is presented by Blum [4], whose theoretical and empirical investigation on the effects of transportation investments on the regional growth, based on the input-output method, detailed by Cobb-Douglas production function, verified for 325 regions of the Federal Republic of Germany, leads to the conclusion that investments in transportation infrastructure induce a regional growth, especially if transportation bottlenecks are removed. The results of this investigation have been confirmed by a lot of other researchers, mentioned earlier in the Section on literature review, so it seems that there is no more need to prove that transportation 
investments are significant factors of regional development. Instead, there is still a discussion on methods of measuring the impact of a transportation investment on a region.

Apart from the abovementioned input-output method, applied in the form of econometric Cobb-Douglas production function with assumed measures for the input and output side, as for instance: regional gross added value, population density, number of railroad stations, kilometres of traffic roads, other measuring methods are used, above all the cost-benefit or multi-criteria analysis. According to the EU Guide to Cost-Benefit Analysis of Investment Projects [17], this method is structured in seven steps, two of which are the analysis steps, namely, financial and economic analyses. A representative example of application of the method is the case of Madrid-Sevilla high-speed train (HST), for which the cost-benefit analysis has been performed [33].

In the general theoretical sense the investments mean the use of money in order to obtain new values. The investments in railway transport can be divided into professional qualification and training of the employees, and into the construction, modernization and reconstruction of the means. In order to make the right decision on the "entry" into an investment program it is necessary to make an investment study. The investment study must be the basis in making the investment decisions. The investment study gives the following evaluations: financial market efficiency of the project (financial analysis), and social and economic efficiency of the project (economic analysis).

In producing the financial analysis on the basis of market prices, the project inputs and outputs are analysed thus producing the estimate of values that will be realized and will belong to the legal subject after the project has been completed. The economic analysis follows the project from a wider social aspect, i.e. uses the "corrected" prices from which duty, taxes and subsidies are subtracted. In railway sector the financial and economic analyses are regularly performed. The financial analysis is suitable from the aspect of the operator - carrier, whereas social analysis is suitable from the aspect of the infrastructure manager. The analysis is done in static and dynamic conditions. In static conditions one target year - representative year - is observed. The indicators in the representative year are compared with the similar lines. In this way a fast and simple result can be obtained. The drawback of the static approach lies in the selection of the representative year, and in neglecting the project lifecycle. The dynamic approach analyses the project from year to year and takes into consideration the entire project lifecycle. Such approach delivers a better picture about the entire project.
Since the project is evaluated for a longer period of time, 25 years in this case of PMR, it is not possible to determine reliably all the actual elements of the calculation. Therefore, the following financial indicators are taken: net present value (NPV), internal rate of return (IRR), relative net present value of the project, and return on the investment period.

Net present value (NPV) is defined as a sum of values of annual net incomes (profits) in the economic flow (schedule) reduced to their value in the project starting year.

The value of the net present value is calculated according to the expression:

$$
N P V=-C_{0}+\sum_{t=0}^{n} \frac{C_{t}}{(1+r)^{t}}
$$

where

$t$ - time of cash flow,

$n$ - total time of the project,

$r$ - discount rate,

$C_{0}$ - capital outlay at the beginning of the investment time $(t=0)$,

$C_{t}$ - net cash flow (the amount of cash) at time $t$.

The discount rate needs to be estimated realistically. The real rate would correspond to the amount of the loan interest rate taken in order to finance the project. In the European Union the discount rate is between four and six percent. The project is cost-effective if the net present value is positive.

When the net present value is reduced to zero, the internal rate of return is obtained. The internal rate of return represents the project effectiveness.

The internal rate of return is obtained according to the expression:

$-C_{0}+\sum_{t=0}^{n} \frac{C_{t}}{(1+I R R)^{t}}=0$

where:

$t$ - time of cash flow,

$n$ - total time of the project,

$I R R$ - internal rate of return,

$C_{0}$ - capital outlay at the beginning of the investment time $(t=0)$

$C_{t}$ - net cash flow (the amount of cash) at time $t$.

The internal rate of return should be greater than the interest rate of the loan on the capital market [35].

The extension of the cost-benefit analysis to the multi-criteria analysis does not also liquidate the problem of assessing the non-financial areas. For instance, the report on High-speed Railway between Schiphol Amsterdam Airport and the German Ruhrgebiet [34] states explicitly that some preventive maintenance items as demolition of houses or destruction of rare flora and fauna habitats were left without valuation by the researchers. These limitations of the cost-benefit and multi-criteria analysis caused the authors of the paper to use another approach of valuating the impact of transport investment. 
Apart from the above criticism and the previously mentioned short period of time, the analysed PMR investment exists, and next reasons to use another approach come from the assumptions of the cost-benefit and the proposed modified falsification method, supported by the point-percentage method. The first one assumes that there is one final assessment in money terms: profitable or non-profitable (loss), which exclude each other, which can cause in practice that some negative aspects of the transportation investments disappear from the eyes of the decision makers, if they are provided with a final (general) positive result. The second one says that the object of assessment, i.e. economic system, which is a kind of a social system [32], is dynamic and complex, which makes the final positive or negative result not so obvious, not so clear or fuzzy, because for instance, a positive result in general does not mean (exclude) that there were no deteriorations in some partial (internal) areas or aspects, and vice versa. Especially from the sustainability point of view [28], perceiving all parts of the assessed object in mutual interactions, a partial deterioration, or not the same rate of development as the other parts, adversely affects other interacting parts, even if the whole system is positively estimated. Therefore, two hypotheses are proposed to be verified: positive and negative, instead of one: positive or excluding negative. This approach gives also such a practical advantage that both hypotheses (and their results) are of the same range of importance for the decision makers. The proposed in the previous Section point-percentage method to verify the hypotheses is a kind of qualitative method of assessment (though the results are expressed in points and percentages), preferred to be used on the base of the authors' expert knowledge and practice, which of course does not prevent from applying a quantitative one, for instance econometric or statistic. The method of calculation is rather not complicated. The first four assessment aspects of PMR are taken, i.e. social, economic, innovation, and sustainability. If possible, some more detailed criteria are formulated for them, as for instance historical or financial. The authors decided to choose one hundred points and divide them on positive and negative hypotheses according to the assessment criteria. For instance, in the case of estimation of PMR impact on regional development in the social aspect according to the transport accessibility criteria, 70 points went to positive hypothesis and 30 points to the negative one based on the subjective expert evaluation of the authors. The same method of calculation has been used for other aspects and criteria, which allows making a sum of points allocated to positive and negative hypotheses, for instance 200 and 400 points, respectively (Table 4). Finally, if the sum of points calculated for an individual hypothesis, for instance a negative one with 200 points, is divided by the sum of points of two hypotheses, i.e. 600 points, then the share of 33\% versus $67 \%$ can be calculated.

\section{IMPACT OF PMR ON THE POMERANIAN REGION}

Based on the above presented course of reasoning the impact of the PMR investment on regional development is analysed in four assessment aspects: social, economic, innovation, and sustainability. The main question in relation to the assessment of the impact of PMR in the social aspect is as follows: was this investment or is it still needed by the Pomeranian region society? The answer to this question seems to be hidden mainly in the history of the railway and the unbalanced social accessibility to regional transportation network, which can also function as the two criteria of assessment.

Based on the literature study [19], a precursor of the PMR was the so-called Kokoszkowska Railway, which started its operations over 100 years ago between Wrzeszcz - Kokoszki and Stara Piła on $1^{\text {st }}$ May 1914. As a part of the shortest route, which connected Gdańsk (the Pomeranian region capitol), and Kashubia (the poor western rural subregion), and led further to Berlin in Germany, it functioned for almost 31 years, when it was destroyed by withdrawing German troops during the Gdańsk battle in 1945. The destruction of the railway caused that the social relations and some transportation needs of the region, which the railway was satisfying, were disrupted suddenly. As a result, a great and a deep-seated wish to recover the line were being expressed in the form of journalistic writings, historic books, fun club, and even a movie. All these elements initiated from time to time a social discussion on the railway with a presence of authorities, politicians, executives of transportation companies and other related bodies. However, despite many ideas on reconstruction or other use of the former Kokoszkowska Railway there was no agreement achieved until 2005. That year, the so-called conception of Tri-City Railway Bypass was elaborated. This project initiated a feasibility study, which started in October 2008 and finished in 2011, due to many decision options and public consultations. Finally, a recommendation to build a 19.5 km long two-railway route between Gdańsk-Wrzeszcz and Gdańsk-Osowa, through Gdańsk Airport, was taken. In addition, this line connects with another already existing railway line, which links Gdynia with Kościerzyna through Kartuzy, which are the main cities of Kashubian rural subregion. And, after a 5-year construction period, PMR started its daily operations on $1^{\text {st }}$ September 2015.

This history includes a relation to the second criterion of pros or cons to the investment; namely, the unbalanced social accessibility to regional transportation 
network. It was mentioned in the railway history, that it was and actually is a part of the line connecting Gdańsk and Gdynia with the Kashubian subregion. Gdańsk together with Sopot and Gdynia create the so-called Tricity metropolis, inhabited by more than one million inhabitants living on $420 \mathrm{~km}^{2}$ of area, urbanised and industrialised centre, where social and business life is concentrated, Voivodeship authorities are located, etc. This metropolis has got a relatively well-developed transportation network, which is based on the Tricity Fast Urban Railway (FUR), supported by bus, trolleybus and tram operators. In contradiction, the outlying to Tricity area, especially the Kashubian subregion, suffered good transportation network, which could be assessed on a satisfactory mark. This situation resulted in the differentiation in transportation accessibility for people living in the metropolis and outside of it, causing also the so-called problem of social exclusion for the latter one. So, the new investment in the $19.5 \mathrm{~km}$ long PMR line can be perceived as a great enterprise to remove the transport accessibility unbalance between the centre and the rest of the region, since this line also functions as a new link to the exiting railway line leading to Kartuzy and Kościerzyna, thus connecting the people living in the rural Kashubian subregion with the Tricity metropolis. With no doubt, an important element of the accessibility improvement to the regional transportation network is the international Gdańsk Lech Walesa Airport, which has a direct connection, just thanks to the PMR trains, to Tricity and the mentioned main cities of Kashubia (Kartuzy, Kościerzyna).

The above described historic and transportation unbalance assessment criteria of PMR impact on the Pomeranian region in the social aspect allow to state that the investment was socially needed, and not excluding some possible examples of negative impact, the overall social assessment is in favour of a positive impact. Particularly, the allocation of 100 points to the negative and positive impact for each criterion is as follows: 10 to 90 points go in favour of positive historic judgement of meeting the regional society needs, and $30 / 70$ points reflect the assessment of the removal of the transportation accessibility unbalance by the investment, for negative and positive hypothesis, respectively.

Table 1 - Financial effectiveness of PMR [20]

\begin{tabular}{||l||c|c|}
\hline \multicolumn{1}{|c|}{ Indicators } & Diesel line & Electric line \\
\hline \hline Financial net present value & $\begin{array}{c}-760,060,927 \text { PLN } \\
(-181 \text { Mill. euro })\end{array}$ & $\begin{array}{c}-797,406,936 \text { PLN } \\
(-190 \text { Mill. euro })\end{array}$ \\
\hline \multirow{2}{*}{ Financial net present value of own capital } & $\begin{array}{c}-335,502,771 \text { PLN } \\
(-80 \text { Mill. euro })\end{array}$ & $\begin{array}{c}-328,644,762 \text { PLN } \\
(-78 \text { Mill. euro })\end{array}$ \\
\hline Financial internal rate [\%] & -5.46 & -5.20 \\
\hline Financial internal rate of own capital [\%] & -3.96 & -3.47 \\
\hline \hline
\end{tabular}

Shifting into the economic aspect of impact assessment of PMR on the Pomeranian region, the main question is as follows: has this investment appeared to be profitable, or if not, when is it expected to be profitable, if at all? Thus, the answer is sought through the assessment of the PMR investment financial criteria, and according to a wider economic perspective, called regional economics. Based on the feasibility study [20], all the four main indicators (Table 1), which measure the financial effectiveness of this investment, are reported to be negative for two variants: diesel or electric line. It means that PMR is not a profitable investment; of course, with a vision of being profitable, but in a very far future.

Based on the actual data, the total cost of the investment in the cheaper diesel version, with plans of electrifying the railway, amounted in the years 2008 2017 to about 1,200 Mill. PLN (about 286 Mill. euro), financed in the amount of 656.5 Mill. PLN (about 156 Mill. euro) from the EU funds [21, 22]. The actual economic situation of PMR shows also that the income from the sales of tickets in the amount of 2 Mill. PLN (about 0.5 Mill. euro) is lower than the operational costs of 17 Mill. PLN (about 4.1 Mill. euro), which means that the operational activity of PMR is subsidised in the amount of about 15 Mill. PLN (about 3.6 Mill. euro) from the Voivodeship funds every year [23]. The negative results also mean that the investment has an adverse effect on the regional GDP in financial terms. Of course, there is also a positive effect of the investment on the reduction of the unemployment level. However, due to the low regional unemployment rate $(4.7 \%)$ the reduction was not calculated.

Summarising, it has to be said that in the perspective of investment financial indicators, PMR appeared to be a not-profitable investment with a yearly operational loss of about 3.6 Mill. euro for the Pomeranian region. However, in a wider economic context, this is in the perspective of regional economics, all the expenses on PMR, excluding subventions, mean also an income for the PMR staff, who are mostly inhabitants of the region, and suppliers of the materials and services, which are also located mainly in the region. This high-value investment (worth about 286 Mill. euro) was and still is a business-generating factor in the region, since during the construction works and after them, for instance, new housing estates are reported to have 
risen alongside the railway, supported by social and service facilities as park-and-ride areas, roads, shops, service points, gardens, schools, kindergartens, etc. [24]. Apart from the abovementioned business-generating effects, the regional economics also receives benefits in the form of [20]:

- time savings (about 15.9 Mill. euro / year),

- cost reduction on road traffic overtaken by PMR (about 9.5 Mill. euro / year),

- cost reduction in accidents (about 2 Mill. euro / year).

Thus, the final economic assessment is not clearcut, nevertheless, taking into account the finances of PMR, especially the subvention problem, the proposition to allocate 100 points is just 90 to 10 in favour of the negative assessment. However, considering the broader impact of PMR on the regional economic development, the subjective judgement is rather positive in the share of 30 to 70 points for the negative and positive hypotheses, respectively.

Approaching the problem of impact assessment of PMR on the Pomeranian region in the innovation aspect, it is necessary first to define how the innovativeness is understood. According to the Oslo Manual: "An innovation is the implementation of a new or significantly improved product (goods or service), or process, a new marketing method, or a new organisational method in business practices, workplace organisation or external relations" [25]. Applying this definition of innovation to the PMR case, it could be stated without any other evidences that the investment is innovative, because it is new; or speaking colloquially, it is a construction which was built from scratch. However, this thesis is true only from the regional point of view. In the case of innovativeness assessment it should be benchmarked to the European or US standards. Because the investment was co-financed from EU funds, the EU application procedure required PMR to meet the European standards, at least including innovativeness in many fields, mainly technical, customer service, and safety, and sustainability. The selected data on the abovementioned fields are presented in Table 2. They can be supported by many other facilities, for instance, dynamic information system for passengers, monitoring system for trains, railways and train stations, access for disabled people, and integrated ticket and timetable with other transportation means. As they are standards, there is no need to describe them in more detail. Due to the subjective judgement of the railway innovativeness, the authors decided to make a technical visit to the whole line and check the PMR train services. The technical visit included infrastructure and the operative part of PMR. Also, when PMR train service is observed, it has to be checked during different periods of the day (morning and afternoon rush hours and off-peak hours), and different days in the week (Monday, Wednesday, Thursday, and Saturday). The conclusion of the technical visit was that especially the design of stations performed by the artists and technologically advanced equipment of trains and stations makes a great impression on customers - passengers. So, according to the expert opinion, PMR is a noticeable and justified element of innovativeness on the Pomeranian transportation map, and coming to the assessment, 80 from 100 points go in favour of the positive hypothesis on the innovation impact of PMR on regional development.

Shifting the research into the impact assessment of PMR on the Pomeranian region in the sustainable aspect, it should be stated that sustainability is usually equated with the terms of "resources for the future" or "environmentally desirable" ones [28]. Of course, taking care about natural resources is very important, if not viable. Nevertheless, to live in a sus-

Table 2 - Innovation criteria of PMR [26, 27]

\begin{tabular}{||l|l||}
\hline \multicolumn{1}{|c|}{ Criteria } & \multicolumn{1}{c||}{ Description } \\
\hline \hline Length of the railway & $19.5 \mathrm{~km}$ \\
\hline No. of crossroads & 21 \\
\hline No. of bridges & 41 \\
\hline No. of railway stops & 10 \\
\hline No. of passages for animals & 36 \\
\hline Trains & Diesel trains of PESA SA136, SA137, SA138; powered by innovative engines that \\
meet the strict requirements 2004/26/EC
\end{tabular}


tainable way seems to mean something more than living in a natural environment, because it includes also cultural, social, political, economic, technical, etc. spheres. Due to their mutual relations, or maybe a better term is multi-aspect and level dependency, they have to be balanced, or to use other words: integrated, managed, coordinated, traded-off, etc. If the results of these activities were named as results of sustainability, integrity, coherence, holism, systemism, optimisation, emergentism, interdependence, synergy, etc., it would not be so much important as to have the ability to think and act in one of the above-listed activities at least, because sustainability is the only aspect, which puts the other partial aspects together, thus allowing to avoid sub-optimisation. Therefore, the authors agree with the opinions, which maintain that sustainability is a system ability to develop itself in all its aspects taken together [29]. If perceiving the Pomeranian region as a system, which should develop in a sustainable way, then one of its elements (subsystem), i.e. PMR, should also be sustainable in relation to other aspects of the region. Three assessments of the PMR impact on the regional development in social, economic and innovation aspects have been already done, but as partial assessments. In the sustainability aspect they are put together, and although the overall assessment is positive, since the regional development in two aspects is positive, thus maintaining, if not improving its sustainability, there is one of them, i.e. economic, where the negative assessment has prevailed with 120 points $(90+30)$ in comparison to $80(10+70)$ points for the positive assessment. It means that in the economic aspect the Pomeranian regional development has not been sustainable, because economic circumstances of the region have deteriorated in relation to the development in other aspects.

Taking into account how PMR has been a great investment for the Pomeranian region, there is still one important aspect of sustainability, not estimated yet, and this is the environmental aspect in sense of PMR interference with the nature. Based on the data included in the report on the impact of PMR on the environment [30], the interfered environmental elements with precautions taken, have been presented in Table 3.

Since not all bad occurrences can be foreseen, some risk mitigation precautions are covered by the insurance policy. In addition to the above qualitative description of the environmental influence of the PMR investment, some quantitative data are available. It is estimated that about $60 \%$ of road traffic, mainly passenger cars, are overtaken by the railway, which in terms of money means 9.5 Mill. euro/year savings on costs of car exploitation, and 0.7 Mill. euro/ year of savings on costs of pollution is also reported [20]. Thanks to the precautions taken to protect the environment (Table 3), the emission of noise and other pollutants are kept under the limits allowed by the regulations. Also, the protection of the flora and fauna is ensured. Finally, taking into account the type and size of precautions taken and the estimated savings, the PMR can be named as environmentally friendly investment, which allows the authors to propose a share of 20/80 in favour of the positive assessment. However, being an environmentally friendly investment stands also for one of many reasons why the PMR requires so many infrastructural elements on such a short line of $19.5 \mathrm{~km}$. Together with the requirements to construct the line according to high technical standards in the urbanized area of Tricity, it is also subject to protecting the fauna, flora, six landscape parks and reserves, and a lot of nature monuments. These are the main reasons why PMR is a highly important infrastructure investment.

The above presented four assessments of the PMR impact on the Pomeranian regional development of social, economic, innovation and environmental perspectives can be put together in one comprehensive assessment. This comprehensive view, which can be also called a sustainable one in its full holistic meaning, is formulated to give the answer to the research hypotheses on positive and negative impact on the

Table 3 - Environmental aspect of PMR [30]

\begin{tabular}{|c|c|}
\hline Interfered element of environment & Precautions \\
\hline Transformation of the earth's surface and soil & Minimum of technical and mechanical works; recultivation of 3 Mill. $\mathrm{m}^{3}$ \\
\hline Surface water and groundwater & Dehydration system; $4-5 \%$ of track bed transverse \\
\hline Noise & Vibration isolating securities; acoustic screens \\
\hline Air pollution & $\begin{array}{l}\text { Internal combustion rail trains, which meet exhaust gas regulations - } \\
\text { 2004/26/EC }\end{array}$ \\
\hline Flora & 75 thousand trees and other plants were planted; green fields \\
\hline Fauna & 36 passages for animals \\
\hline Waste management & Communal selective waste collection system \\
\hline $\begin{array}{l}\text { Bad accidents, breakdowns, fire hazards, } \\
\text { terrorists }\end{array}$ & $\begin{array}{l}24 / 7 \text { monitoring system; emergency and fire brigade units; help } \\
\text { interactive kiosks; AEDs }\end{array}$ \\
\hline
\end{tabular}


Mankowski C, Weiland D, Abramović B. Impact of Railway Investment on Regional Development - Case Study of Pomeranian...

Table 4 - Comprehensive assessment of PMR impact

\begin{tabular}{|c|c|c|c|}
\hline \multicolumn{2}{|c|}{ Assessment aspect } & Negative hypothesis & Positive hypothesis \\
\hline \multirow{2}{*}{ Social } & historical & 10 points & 90 points \\
\hline & transport accessibility & 30 points & 70 points \\
\hline \multirow{2}{*}{ Economical } & investment profitability & 90 points & 10 points \\
\hline & regional economics & 30 points & 70 points \\
\hline \multicolumn{2}{|l|}{ Innovation } & 20 points & 80 points \\
\hline \multicolumn{2}{|l|}{ Environment } & 20 points & 80 points \\
\hline \multirow{2}{*}{ Comprehensive } & (sum) & 200 points & 400 points \\
\hline & (share) & $33 \%$ & $67 \%$ \\
\hline
\end{tabular}

region. For this purpose, Table 4 is constructed, and it includes the four assessments and the final comprehensive results in the form of a sum of points and percentage share of each hypothesis (if to divide 200 by 600 and 400 by 600 ). Therefore, from the point of view of the methodology applied in this case it can be stated that the negative hypothesis is true in 33\%, while the positive one in $67 \%$ (rounded-up), or speaking explicitly in relation to PMR that the impact of PMR on the regional development has appeared to be negative in $33 \%$ and positive in $67 \%$. It should be also added, especially from the sustainability point of view, that there is one aspect, i.e. the economic one, in which negative assessment has prevailed, which means that the Pomeranian regional development deteriorated in this aspect.

\section{CONCLUSION}

The above-presented results show how difficult is the research process focused on the assessment of an investment in the transportation area. Despite a large amount of literature on the methodology, there is still the problem of choosing the right one, not to mention the issues with applying the selected methods to a real case. In the case of PMR, a modified method of two hypotheses detailed by point-percentage method, supported by cost-benefit qualitative and quantitative criteria was applied. The obtained results allow the formulation of the final conclusion that the PMR impact on the regional development has proven to be negative in $33 \%$ and positive in $67 \%$, justified by the more detailed criteria in the related aspects. However, shifting to a criticism of the above applied methodology, it should be stated that the downside of the research is its subjective judgement, which is based on the authors' expert opinions. So, the recommendations go in the direction of doing a more objective research with the application of more sophisticated methods and tools than the ones used. However, there is no certainty that the obtained results would be more accurate.

Furthermore, one of the most important research outputs that were found is that the subjective expert method of assessment can be criticized together with the simple method of calculation. However, an alternative usage of more sophisticated methods does not mean the obtained results would be more reliable. Nevertheless, an idea to apply a semi-quantitative fuzzy-set theory for transport investment impact evaluation has taken the authors' consideration as a topic of future research.

CEZARY MAŃKOWSKI, Ph.D. ${ }^{1}$

E-mail: ekocm@ug.edu.pl

DARIUSZ WEILAND, M.Sc. ${ }^{1}$

E-mail: d.weiland@ug.edu.pl

BORNA ABRAMOVIĆ, Ph.D. ${ }^{2}$

E-mail: borna.abramovic@fpz.hr

${ }^{1}$ Uniwersytet Gdański, Wydzial Ekonomiczny

A. Krajowej 119/121, 81-824 Sopot, Polska

2 Sveučilište u Zagrebu, Fakultet prometnih znanosti

Vukelićeva 4, 10000 Zagreb, Hrvatska

\section{WPŁYW INWESTYCJI KOLEJOWEJ NA ROZWÓJ REGIONALNY - STUDIUM PRZYPADKU POMORSKIEJ KOLEI METROPOLITALNEJ}

\section{ABSTRAKT}

Z punktu widzenia rozwoju regionalnego nowe inwestycje mają zawsze ogromne znaczenie, ponieważ przede wszystkim pobudzają regionalną gospodarkę, a tym samym poprawiają standard życia mieszkańców. Również z punktu widzenia badań literaturowych nowe studium przypadku dotyczące wpływu inwestycji na rozwój regionalny może być postrzegane jako wkład do rozwoju badań. Wpływ analizowanej inwestycji jest mierzony $w$ następujących aspektach: (1) społecznym, (2) ekonomicznym, (3) innowacyjnym i (4) środowiskowym, które również spełniają główne kryteria oceny tego wpływu. Z uwagi na fakt, że stosunkowo niedawno, tj. 1 września 2015 r., po pięciu latach prac budowlanych i ponad stuletniej historii, zakończyła okres inwestycyjny $i$ rozpoczęła swoją działalność Pomorska Kolei Metropolitalna (w skrócie PKM), pojawiła się możliwość przestudiowania tego przypadku. W wyniku zastosowania autorskiej metody oceny jakościowej i ilościowej wpływu PKM na rozwój regionu pomorskiego, w konkluzji stwierdza, że wpływ ten okazał się negatywny w 33\% i pozytywny w $67 \%$.

\section{SŁOWA KLUCZOWE}

kole; region; inwestycja; oszacowanie; 


\section{REFERENCES}

[1] Kamińska T. Makroekonomiczna ocena efektywności inwestycji infrastrukturalnych na przykładzie transportu. [Macroeconomic assessment of the effectiveness of infrastructure investments on the example of transportation]. Gdańsk, PL: Wyd. Uniwersytetu Gdańskiego; 1999.

[2] Wojewódzka-Król K. Transport a rozwój regionalny. [Transport and regional development]. Zeszyty Naukowe Uniwersytetu Gdańskiego. Ekonomika Transportu i Logistyka. 2015;55: 57-67.

[3] Kaźmierski J. Logistyka a rozwój regionu. [Logistics and the regional development]. Łódź, PL: Wyd. Uniwersytetu Łódzkiego; 2009.

[4] Blum U. The Effects of Transportation Investment on Regional Growth: A Theoretical and Empirical Investigation. Papers of the Regional Science Association. 1982;49: 169-184.

[5] Domańska A. Wpływ infrastruktury transportu drogowego na rozwój regionalny. [Impact of road transport infrastructure on regional development]. Warszawa, PL: Wyd. Nauk. PWN; 2006.

[6] Impact of Transport Infrastructure Investment on Regional Development. Paris: OECD Publications; 2002. Available at: https://www.itf-oecd.org/sites/default/ files/docs/02rtrinveste.pdf [Accessed 10 ${ }^{\text {th }}$ June 2018].

[7] Ivanova O. The role of transport infrastructure in regional economic development. The Institute of Transport Economics (TØI). TØI Report 671/2003, 2003.

[8] Tavasszy LA, Burgess A, Renes G. Final Publishable Report: Conclusions and recommendations for the assessment of economic impacts of transport projects and policies. IASON (Integrated Appraisal of Spatial economic and Network effects of transport investments and policies), Deliverable D10. Funded by $5^{\text {th }}$ Framework RDT Programme. TNO Inro, Delft, Netherlands, March 2004. Available at: http://www. transport-research.info/sites/default/files/project/ documents/20060821_162810_15461_IASON\%20 Final\%20Report.pdf [Accessed 15 th June 2018].

[9] Regional Logistics Strategic Plan 2015-2018. Brazzaville: WHO Regional Office for Africa; 2015. Available at: http://apps.who.int/iris/bitstream/10665/ 171496/1/9789290232797.pdf [Accessed $27^{\text {th }}$ July 2018].

[10] Yu N. et al. The growth impact of transport infrastructure investment: A regional analysis for China (19782008). Policy and Society. 2012;31(1): 25-38.

[11] Griškevičiūtè-Gečienèa A, Griškevičienè D. The Influence of Transport Infrastructure Development on Sustainable Living Environment in Lithuania. Procedia Engineering. 2016;134: 215-223.

[12] Michniak D. Main Problems of Transport Infrastructure Development in Slovakia and Effects on Regional Development. Geographia Polonica. 2015;88(1): 21-39.

[13] Popper K. Conjectures and Refutations. London, UK: Routledge and Keagan Paul; 1963.

[14] Szreder M. O weryfikacji i falsyfikacji hipotez. [On verification and falsification of hypotheses]. Przegląd Statystyczny. 2010;2-3: 82-88.

[15] Kauf S, Tłuczak A. Logistyka miasta i regionu: metody ilościowe w decyzjach przestrzennych. [Logistics of the city and the region: quantitative methods in spatial decisions]. Warszawa, PL: Difin; 2008.

[16] Hansen J. A guide to the guidelines: The UNIDO method of economic project evaluation. World Bank, Washington, DC. Staff working paper No. SWP 166, 1973. Available at: http://documents.worldbank.org/curated/en/903231468329395903/A-guide-to-the-guidelines-the-UNIDO-method-of-economic-project-evaluation [Accessed $7^{\text {th }}$ July 2018].

[17] Guide to Cost-Benefit Analysis of Investment Projects: Economic appraisal tool for Cohesion Policy 20142020. European Commission, Directorate-General for Regional and Urban Policy; 2014. Available at: https:// ec.europa.eu/inea/sites/inea/files/cba_guide_cohesion_policy.pdf [Accessed $7^{\text {th }}$ July 2018].

[18] EUNET/SASI Report. Socio-Economic and Spatial Impacts of Transport. Project funded by the European Commission under the Transport RTD Programme of the $4^{\text {th }}$ Framework Programme, Contract: ST-96-SC037. Marcial Echenique and Partners Ltd., Cambridge, UK; 2001. Available at: http://www.transport-research. info/sites/default/files/project/ documents/eunet. pdf [Accessed 10 ${ }^{\text {th }}$ September 2018].

[19] Konopacki T. (ed.) Kolej na PKM. Pomorska Kolej Metropolitarna. [Railway to PKM. Pomeranian Metropolitan Railway]. Gdańsk, PL: Wyd. Pomorska Kolej Metropolitarna SA; 2015. p. 13-17, 156, 172-173.

[20] Studium Wykonalności. [Feasibility study]. Pomorska Kolej Metropolitalna Etap I - rewitalizacja Kolei Kokoszkowskiej" Faza II - realizacja przedsięwzięcia. Wielobranżowa koncepcja programowo-przestrzenna. BPBK, IK, DSC, Województwo Pomorskie, Gdańsk, PL; 2012. p. 18-20, 158, 229. Available at: http://www.pkmsa.pl/glowna/wp-content/uploads/2010/09/DSCAktualizacja-Studium-Wykonalno\%C5\%9Bci-06.03. 2012.pdf [Accessed $7^{\text {th }}$ July 2018].

[21] Ledwoń M. Dofinansowanie projektu PKM zwiększone do 85 procent! [Co-financing of the PKM project increased to 85 percent!] Article at Portal of Pomeranian Voivodeship, Gdańsk, PL, 12.02.2015. Available at: https://pomorskie.eu/-/komisja-europejska-zatwierdzila-zwiekszenie-dofinansowania-projektu-pomorskiej-kolei-metropolitalnej-do-85-procent [Accessed 14 July 2018].

[22] Pomorskie: elektryfikacja i nowy przystanek PKM do 2023 r. [Pomeranian: electrification and a new PKM stop - until 2023]. Article at Portal Onet Tricity, Gdańsk, PL, 04.06.2018. Available at: https://trojmiasto.onet.pl/pomorskie-elektryfikacja-i-nowy-przystanek-pkm-do-2023-r/xyvszOm [Accessed $14^{\text {th }}$ July 2018].

[23] Kołodziejski H. et al. Koncepcja funkcjonowania Szybkiej Kolei Miejskiej w Trójmieście i Pomorskiej Kolei Metropolitalnej w obsłudze transportowej obszaru metropolitalnego oraz integracji transportu publicznego $w$ obszarze metropolitalnym i regionie, $w$ tym integracji taryfowo-biletowej. [The concept of functioning of the Fast Urban Railway in the Tri-City and the Pomeranian Metropolitan Railway in servicing the metropolitan area and integration of public transport in the metropolitan area and the region, including tariff and ticket integration]. Gdańsk, PL: MZKZG, 2015. p. 8. Available at: http://www.metropoliagdansk.pl/ 
upload/files/Koncepcja\%20-20integracja\%20biletowa\%281\%29.pdf [Accessed 15 $5^{\text {th }}$ July 2018].

[24] Koprowski K. Niedźwiednik zyska nowe centrum przy PKM. [Niedźwiednik will gain a new center at PKM]. Article at Portal of Tricity.pl, Gdańsk, PL, 13.10.2014. Available at: https://www.trojmiasto.pl/wiadomosci/ Niedzwiednik-zyska-nowe-centrum-przy-PKM-n84276. html [Accessed $16^{\text {th }}$ July 2018].

[25] Oslo Manual Guidelines for Collecting and Interpreting Innovation Data. Third edition. Paris: OECD Publications; 2005. p. 46.

[26] Kuik J. Charakterystyka techniczna linii. [Technical characteristics of the line]. PKM Portal. Available at: http://www.pkm-sa.pl/glowna/wp-content/uploads/ 2011/09/20110905_PKMtechniczna_KuikJaroslaw. pdf [Accessed $14^{\text {th }}$ July 2018].

[27] Naskręt M. Kierowcy polubili parkingi Park\&Ride przy linii PKM. [Drivers liked Park \& Ride car parks at the PKM railway]. Portal of Tricity.pl, Gdańsk, PL, 4.04.2016. Available at: https://m.trojmiasto.pl/wiadomosci/Kierowcy-polubili-parkingi-ParkRide-przy-lin ii-PKM-n100235.html [Accessed 14 ${ }^{\text {th }}$ July 2018].

[28] Pezzey JCV, Toman MA. The Economics of Sustainability: A Review of Journal Articles. Resources for future, Discussion paper 02-03: 2002; p. 5, 14-15. Available at: www.rff.org/files/sharepoint/Worklmages/Download/RFF-DP-02-03.pdf [Accessed 24 ${ }^{\text {th }}$ July 2018].

[29] Sustainable Development Strategies: A Resource Book. Compiled by B. Dalal-Clayton, S. Bass. Organisation for Economic Co-operation and Development. New York: Paris and United Nations Development Programme; 2002. p. 11 - 13.

[30] Raport Oddziaływania na Środowisko - Streszczenie. [Environmental Impact Report - Summary]. WYG
International, PKM, Gdańsk, PL, 2002. Available at: http://www.pkm-sa.pl/glowna/wp-content/uploads/ 2010/09/ROS_streszczenie_30.03.20111.pdf [Accessed $4^{\text {th }}$ September 2018].

[31] Piętak $\measuredangle$. Review of Theories and Models of Economic Growth. Comparative Economic Research. 2014;17(1): 45-57.

[32] Samuelson P, Nordhaus W. Economics. McGraw Hill Int. New York; 2009. p. 5-8, 438, 440-441.

[33] Rus G, Inglada V. Cost-benefit analysis of the highspeed train in Spain. The Annals of Regional Science. 1997;31: 175-188.

[34] Dijkman H, Koopmans C, Vromans M. Cost-Benefit Analysis of High Speed Rail. CPB Report 00/2, 2000. Available at: https://pdfs.semanticscholar.org/0474/2190d741f319cb85c5f1cb392f161b149480.pdf [Accessed 14th January 2019].

[35] Abramović B, Badanjak D, Blašković Zavada J. The Feasibility of Introducing a New Safety System on Railways. In: $15^{\text {th }}$ International Symposium on Electronics in Traffic ISEP 2007, Ljubljana; 2007.

[36] Berechman J. The evaluation of transportation investment projects. Routledge; 2010.

[37] Barić D, Čurepić D, Radačić Ž. Implementation of relevant methods in assessing traffic-technological projects. Promet - Traffic \& Transportation. 2007;19(5): 329-36.

[38] Amiril A, Nawawi AH, Takim R, Latif SN. Transportation infrastructure project sustainability factors and performance. Procedia - Social and Behavioral Sciences. 2014;153: 90-8.

[39] Joumard R, Nicolas JP. Transport project assessment methodology within the framework of sustainable development. Ecological Indicators. 2010;10(2): 136-42. 